\title{
Interplay of IL6 and CRIM1 on thiopurine-induced neutropenia in leukemic patients with wild-type NUDT15 and TPMT
}

Hyery $\mathrm{Kim}^{1 \dagger}$, Seungwon You $^{2 \dagger}$, Yoomi Park ${ }^{2}$, Jung Yoon $\mathrm{Choi}^{3,4}$, Youngeun $\mathrm{Ma}^{5}$, Kyung Tak Hong ${ }^{3}$, Kyung-Nam Koh ${ }^{1}$, Sunmin Yun ${ }^{2}$, Kye Hwa Lee ${ }^{2,6}$, Hee Young Shin $^{3}$, Suehyun Lee ${ }^{2,7}$, Keon Hee Yoo ${ }^{8}$, Ho Joon Im ${ }^{1 *}$, Hyoung Jin Kang ${ }^{3,4^{*}}$, Ju Han $\mathrm{Kim}^{2 *}$

${ }^{1}$ Department of Pediatrics, Asan Medical Center, University of Ulsan College of Medicine, Seoul, Korea

${ }^{2}$ Seoul National University Biomedical Informatics (SNUBI), Division of Biomedical Informatics, Seoul National University College of Medicine, Seoul 03080, Korea

${ }^{3}$ Department of Pediatrics, Seoul National University College of Medicine, Seoul 03080, Korea

${ }^{4}$ Seoul National University Cancer Research Institute, Seoul, Korea

${ }^{5}$ Department of Pediatrics, Seoul National University Bundang Hospital, Seoul, Korea

${ }^{6}$ Department of Information Medicine, Asan Medical Center and University of Ulsan College of Medicine, Seoul 05505, Korea

${ }^{7}$ Department of Biomedical Informatics, College of Medicine, Konyang University, Daejeon, Korea

${ }^{8}$ Department of Pediatrics, Samsung Medical Center, Sungkyunkwan University School of Medicine, Seoul, Korea

\section{* Correspondence:}

Ju Han Kim, M.D., Ph.D., Hyoung Jin Kang, M.D., Ph.D., and Ho Joon Im, M.D., Ph.D.

Seoul National University Biomedical Informatics (SNUBI), Division of Biomedical Informatics, Seoul National University College of Medicine, 101 Daehak-ro, Jongnogu, Seoul 03080, Korea. Tel: +82-2-740-8320, Fax:+82-2-747-8928 (juhan@snu.ac.kr)

Department of Pediatrics, Seoul National University College of Medicine, Seoul 03080, Korea Tel: Tel: 82-2-2072-3304 Fax: 82-2-3675-0993 (kanghj@snu.ac.kr) 
medRxiv preprint doi: https://doi.org/10.1101/2020.07.21.20158931; this version posted July 25, 2020. The copyright holder for this preprint (which was not certified by peer review) is the author/funder, who has granted medRxiv a license to display the preprint in perpetuity. It is made available under a CC-BY-NC-ND 4.0 International license .

Department of Pediatrics, Asan Medical Center Children's Hospital, University of Ulsan College of Medicine, 88, Olympic-ro 43-gil, Songpa-gu, Seoul 05505, Korea. Tel: +822-3010-3371 Fax: +82-2-473-3725 (e-mail: hojim@amc.seoul.kr)

${ }^{\dagger}$ These authors contributed equally to this work. 
medRxiv preprint doi: https://doi.org/10.1101/2020.07.21.20158931; this version posted July 25, 2020. The copyright holder for this preprint

\section{Abstract}

Background: NUDT15 and TPMT variants are strong genetic determinants of thiopurine-induced hematological toxicity. Despite recent discovery of homozygous CRIM1 effect on thiopurine toxicity, many patients with wild-type NUDT15, TPMT, and CRIM1 still suffer from thiopurine toxicity, and therapeutic failure and relapse of acute lymphoblastic leukemia (ALL).

Methods: Novel PGx interactions associated with thiopurine toxicity in 320 pediatric ALL patients were investigated using whole-exome sequencing technology for the last-cycle 6-Mercaptopurine dose intensity percentage (DIP) tolerated by pediatric ALL patients.

Results: IL6 rs13306435 carriers ( $N=19)$ exhibited significantly lower DIP $(48.0 \pm 27.3 \%)$ than non-carriers $(N=209,69.9 \pm 29.0 \% ; p=0.0016$ and 0.0028 by $t$-test and multiple linear regression, respectively). Of the 19 carriers, seven with both heterozygous IL6

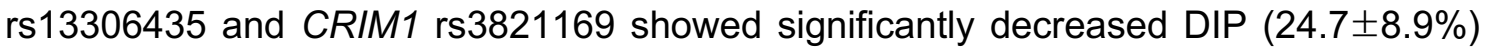
than those with IL6 $(N=12,61.6 \pm 25.1 \%)$ or CRIM1 $(N=94,68.1 \pm 28.4 \%)$ variant only. Both IL6 and CRIM1 variants showed marked inter-ethnic variability. Significant interplay between IL6 and CRIM1 in thiopurine toxicity was suggested. GVB (Gene-wise Variant Burden)-based four-gene-interplay model showed the best odds ratio (8.06) and potential population impact (i.e., relative risk (5.73), population attributable fraction (58\%), number needed to treat (3.67) and number needed to genotype (12.50)).

Conclusions: Interplay of IL6 rs13306435 and CRIM1 rs3821169 was suggested as independent and/or additive genetic determinant of thiopurine toxicity beyond NUDT15 and TPMT in pediatric ALL.

Keywords: IL6, CRIM1, thiopurine toxicity, genetic determinant 
medRxiv preprint doi: https://doi.org/10.1101/2020.07.21.20158931; this version posted July 25, 2020. The copyright holder for this preprint

\section{Introduction}

Despite improvements of combination drug therapy and risk stratification, about $20 \%$ of pediatric acute lymphoblastic leukemia (ALL) patients still suffer from drug resistance and treatment failure due to drug toxicities. In European populations, about $50 \%$ of thiopurine-induced cytotoxic adverse reactions such as severe neutropenia and leukopenia are explained by NUDT15 and TPMT genetic variants [1, 2, 3, 4]. The Clinical Pharmacogenetics Implementation Consortium (CPIC) [5] publishes practical guidelines for the implementation of pharmacogenetic (PGx) testing of thiopurine by using traditional star $\left(^{*}\right)$ allele-based molecular phenotyping for NUDT15 and TPMT $[6,7]$.

According to the established guideline, thiopurine dose is pharmacogenetically titrated based on the known risk variants of NUDT15 and TPMT. However, a substantial proportion of leukemia patients who have no genetic variation in NUDT15 or TPMT still suffer from life-threatening toxicity, which may result in dose reduction and/or discontinuation of thiopurine, resulting therapeutic failure and relapse of leukemia. In an attempt to overcome the PGx gap, CRIM1 rs3821169 homozygote in East Asians has been reported as a novel risk variant of thiopurine toxicity [8]. Heterozygotes of the variant showed only mild effect on thiopurine toxicity with unknown clinical impact. However, its high prevalence ( $T=0.066$, the Phase 3 of the 1000 Genomes Project [9]) and remarkable inter-ethnic variability (see Table 2) might have severely confounded previous PGx studies for thiopurine toxicity. Therefore, investigating PGx interactions of novel genes/variants other than NUDT15 and TPMT variations is urgently needed for preventing thiopurine toxicity and improving pediatric ALL care.

The categorical nature of the traditional star allele haplotype-based method can be complemented by the quantitative nature of Gene-wise Variant Burden (GVB) method for evaluating complex interplays of multiple genes/variants [10]. For instance, 
medRxiv preprint doi: https://doi.org/10.1101/2020.07.21.20158931; this version posted July 25, 2020. The copyright holder for this preprint

designating three categories (i.e., poor (PM), intermediate (IM), and normal (NM) metabolizers) per a gene creates exponentially increasing complexity of $3^{N}$ for a drug with N-gene PGx interactions. NUDT15 and TPMT have already required nine PGx subgroups for thiopurine, which will increase exponentially by new PGx discoveries across different ethnic groups. GVB quantitates the cumulative variant burden of one or more genes into a single score with dimensionality reduction and hence to provide a reliable frame for multiple gene-interaction analysis $[11,12,13]$.

The present study aimed to identify novel PGx interactions associated with thiopurine toxicity in pediatric ALL patients who carry both wild-type (WT) NUDT15 and TPMT (and do not carry CRIM1 rs3821169 homozygote) by using whole-exome sequencing (WES) technology. We identified and evaluated the deterministic effect and their interaction of novel candidate PGx variants on a clinically important hematological toxicity indicator: the last-cycle 6-MP dose intensity percentage (DIP) tolerated by pediatric ALL patients. We provided not only the measures of clinical validity but also the measures of population impact (or clinical utility) including relative risk (RR), population attributable fraction (PAF), number needed to treat (NNT), and number needed to genotype (NNG) [14] for preventing thiopurine toxicity.

\section{Materials and Methods}

\section{Subjects}

We recruited 320 Korean pediatric ALL patients who underwent maintenance therapy with 6-Mercaptopurine (6-MP) from three teaching hospitals, Seoul National University Hospital (SNUH), Asan Medical Center (AMC), and Samsung Seoul Medical Center (SMC), located in Seoul, South Korea. All of the subjects conformed with the exclusion criteria (i.e., relapse of the disease, stem cell transplantation, Burkitt's lymphoma, mixed phenotype acute leukemia, infant ALL, or very high risk of $A L L)$. Patients allocated to 
medRxiv preprint doi: https://doi.org/10.1101/2020.07.21.20158931; this version posted July 25, 2020. The copyright holder for this preprint

standard risk group were treated with Children's Cancer Group (CCG)-1891 [15], CCG1952 [16] or Children's Oncology Group AALL-0331 regimens [17]. In high risk group, CCG-1882 [18], 0601 or 1501 protocols for Korean multicenter studies [19] were used. In Korea, the planned dose of 6-MP was modified from 75 to $50 \mathrm{mg} / \mathrm{m}^{2}$, as many patients who had been given the same dose under the original Western protocol exhibited moderate to severe toxicities during 6-MP administration [20, 21]. Doses of 6-MP during maintenance were adjusted to maintain a WBC count of $2.0-3.5 \times 10^{9} / \mathrm{L}$ with an absolute neutrophil count (ANC) over $500 / \mu \mathrm{L}$, and hepatotoxicity related dose modifications were performed at the discretion of the treating physician. Hematological toxicity as the clinical endpoint was estimated by the tolerated last-cycle 6-MP DIP (\%). The percentage of the actually prescribed amount to the planned dose was defined as the last cycle 6-MP DIP by using the recorded 6-MP dose per meter body surface area over the last cycle (12week) of maintenance. The doses of the last maintenance cycle were considered because dose modification of 6-MP was mainly adopted during early phase of maintenance. Further detailed description of patients and the measurements are summarized in our previous study [8, 20, 21]. The present study was approved by the SNUH, AMC, and SMC Institutional Review Boards. Written informed consent was obtained from each participant.

\section{Whole-exome sequencing and pharmacogenomic subgrouping}

WES data were obtained from pediatric ALL patients and analyzed in a bioinformatics pipeline as previously described [8, 10, 11]. CPIC provides major PGx genes with haplotype definitions and molecular function annotations based on star $\left(^{*}\right)$ nomenclature. We classified ALL patients into PM, IM, and NM groups of NUDT15 and TPMT according to CPIC classifications [6, 7]. We considered NMs as WTs for both genes. We found that no star name designated yet to novel (or candidate) PGx genes. Thus, for the purpose 
medRxiv preprint doi: https://doi.org/10.1101/2020.07.21.20158931; this version posted July 25, 2020. The copyright holder for this preprint

of the present study, we defined WTs for CRIM1 and IL6 as non-carriers of CRIM1 rs3821169 homozygote and IL6 rs13306435 hetero/homozygote, respectively (Table 1). Haplotypes were determined by PHASE 2.1.1 [22, 23].

\section{Gene-wise variant burden for evaluating single- and multi-gene effects}

Gene-wise variant burden (GVB) analysis was performed to evaluate the aggregated impact of both common and rare variants $[10,11]$. The GVB of a coding gene for each individual was defined as the geometric mean of the SIFT (Sorting Intolerant From Tolerant) [24] scores of the coding variants (with SIFT score <0.7) in the coding gene, where $G V B{ }^{G}$ denotes the GVB score of gene $G$ [range: 0.0 1.0]. The more deleterious variant burden, the lower the score. Multigene effect was evaluated by defining $G_{V} B^{A, B, C}$ as the geometric mean of $\mathrm{GVB}^{A}, \mathrm{GVB}^{B}$ and $\mathrm{GVB}^{C}$ [range: $0.0 \sim 1.0$ ]. Gene-variant interaction was considered by defining conditional $\mathrm{GVB}^{\mathrm{G}^{\wedge}(\text { variant) }}$ as the GVB score of gene $G$ dependent on the presence or absence of the specified variant. For example, $\mathrm{GVB}^{\text {CRIM1^(rs13306435) }^{2}}$ equals GVB ${ }^{\text {CRIM1 }}$ when $r s 13306435$ is present and vanishes to a WT score of 1.0 when absent.

\section{Inter-ethnic variability of allele frequencies and molecular phenotypes}

By using the 2504 whole genome sequences with multiple ethnicities provided by the 1000 Genomes Project phase 3 [9], we investigated inter-ethnic distributions of the PGx alleles and haplotypes with their molecular phenotypes associated with thiopurine toxicity (see Table 2).

\section{Statistical analysis}


medRxiv preprint doi: https://doi.org/10.1101/2020.07.21.20158931; this version posted July 25, 2020. The copyright holder for this preprint

The last-cycle 6-MP DIPs (\%) according to different PGx groups were tested by Student's t-test or one-way ANOVA with posthoc Tukey test. Multiple linear regression was also applied to adjust confounding clinical variables. The powers of GVB $^{\text {NUDT15 }}$, GVB ${ }^{\text {TPMT }}$, $\mathrm{GVB}^{\mathrm{CRIM1}}$, and $\mathrm{GVB}^{I L 6}$, and their combinations for predicting 6-MP DIP were systematically evaluated by analyzing ROC (receiver operating characteristic) curves across eight different DIP cutoffs (i.e., $10 \%, 15 \%, 25 \%, 35 \%, 45 \%, 60 \%, 80 \%$, and $100 \%$ ) in terms of AUCs (areas under the ROC curves) (see Figs. 3 and 4). An ROC curve is a two-dimensional depiction of classification performance integrating all sensitivity and specificity values at all cutoff levels [25]. All statistical analyses were performed using the $\mathrm{R}$ statistical package (version 3.5.1). R package 'pROC' was used for calculating AUC values [26]. The optimal cutoff for the GVB score was determined by maximizing Youden's index [27]

GVB $^{C R I M 1^{\wedge}\left(r s 13306435^{*}\right)}$ was applied to control the potential confounding effect of the impressively high carrier frequency in East Asians $(43.7 \%(=220 / 504))$ compared to other ethnicities (0.2 9.4\%) and of mild effect of heterozygote on thiopurine toxicity.

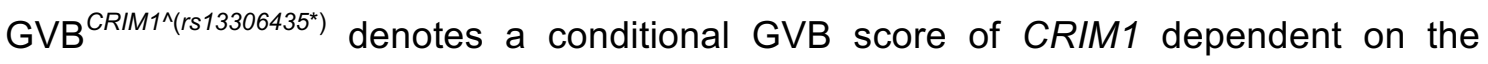
presence or absence of homozygous rs3821169 variant (denoted as rs3821169*). It equals GVB ${ }^{C R I M 1}$ when the subject carries homozygous $r$ s3821169 variant and otherwise vanishes to 1.0 .

\section{Results}

\section{IL6 rs13306435 as a novel pharmacogenetic variant on thiopurine toxicity}

Table 1 describes clinical characteristics of the whole 320 pediatric ALL patients according to their PGx subgroups; 80 non-WTs (i.e., IMs or PMs) for NUDT15 (N=72) and/or TPMT $(N=9), 115$ all WTs (for all of the four genes), and 125 both WTs (for 
medRxiv preprint doi: https://doi.org/10.1101/2020.07.21.20158931; this version posted July 25, 2020. The copyright holder for this preprint

NUDT15 and TPMT) who carried CRIM1 rs3821169 and/or IL6 rs13306435. Of the 125 both WTs, 94, 12, 11, and 8 patients were heterozygous-CRIM1, heterozygous-IL6, homozygous-CRIM1, and IL6-and-CRIM1 variant groups, respectively (Table 1, Fig. 1).

We used all WTs as non-PGx controls $(N=115)$ for the following analysis. We replicated previous PGx findings of NUDT15, TPMT, and homozygous-CRIM1. The tolerated 6-MP DIPs of non-WTs (i.e., IM or PM) for NUDT15 $(47.1 \pm 30.5 \%, N=72)$ and/or for TPMT $(56.6 \pm 33.6 \%, N=9)$ were significantly lower than that of all WTs $(71.3 \pm 29.6 \%, N=115)(p<0.001$, Table 1). The homozygous-CRIM1 group (dark blue circle in Fig. 2) exhibited significantly lower 6-MP DIP of than all WTs before $(N=16$, $44.6 \pm 35.2 \%)$ or after $(N=11,42.3 \pm 35.0 \%)$ controlling the five subjects with NUDT15 $(59.76 \pm 37.24 \%)$ or IL6 $(9.77 \%)$ variants.

To control the PGx effect of NUDT15, TPMT, and homozygous-CRIM1 on thiopurine toxicity, we extracted 228 samples who are non-carriers of these variants. We explored them for further discovery of novel PGx variant. We found that carriers of a novel variant, IL6 rs13306435 (N=19, 48.0 $\pm 27.3 \%)$, exhibited significantly lower 6-MP DIP than non-carriers $(N=209,69.9 \pm 29.0 \%)$ by Student's $t$-test $(p=0.0016)$ and multiple covariates linear regression $(p=0.0028)$. Further, of the 19 carriers, we found that seven patients with both IL6 rs13306435 and heterozygous-CRIM1 showed significant decrease in 6-MP DIP $(24.7 \pm 8.9 \%)$ compared to the 12 patients harbouring IL6 rs13306435 variant only $(61.6 \pm 25.1 \%)$ (brown circle in Fig. 2). Potential interplay between IL6 and CRIM1 variants were suggested, which was further supported by the following finding that the seven patients with both IL6 and CRIM1 variants showed significantly lower 6-MP DIP $(24.7 \pm 8.9 \%)$ than 94 heterozygous-CRIM1 carriers (68.1 $\pm 28.4 \%$, light blue circle in Fig. 2). 
medRxiv preprint doi: https://doi.org/10.1101/2020.07.21.20158931; this version posted July 25, 2020. The copyright holder for this preprint (which was not certified by peer review) is the author/funder, who has granted medRxiv a license to display the preprint in perpetuity.

\section{Interplay of IL6 and CRIM1 variants in thiopurine toxicity}

Figure 1 exhibits the distributions of the last-cycle 6-MP DIPs (\%) of 115 all WTs (Fig. 1(a)) and 125 CRIM1 and/or IL6 variant carriers who are both WTs (for NUDT15 and TPMT) and consist of four PGx groups; heterozygous-CRIM1 $(N=94)$, heterozygous-IL6 $(N=12)$, homozygous-CRIM1 (N=11), and IL6-and-CRIM1 (N=8) (Fig. 1(b)-(e), see Table 1). Homozygous-CRIM1 and IL6-and-CRIM1 (44.6 $\pm 35.2 \%$ and $24.7 \pm 8.9 \%$, respectively, Fig. 1(d, e)) groups showed significantly lower 6-MP DIPs than all-WT and heterozygousCRIM1 groups $(71.3 \pm 29.6 \%$ and $68.1 \pm 28.4 \%$, respectively, Figs. $1(a, b))$ by one-way ANOVA ( $p=0.0001$; adj. $p<0.05$ posthoc Tukey). Further, IL6-and-CRIM1 group showed significantly lower 6-MP DIP (44.6 $\pm 35.2 \%)$ than heterozygous-IL6 group $(61.6 \pm 25.1 \%$; adj. $p<0.05$, posthoc Tukey) (Fig. $1(\mathrm{c}, \mathrm{e}))$. All of the $10(=7+1+1+1)$ patients with both IL 6 and CRIM1 variants (in red numbers in Fig. 2) exhibited the lowest DIPs (9.77 32.68\%) among all subgroups of the whole PGx groups. Thus, significant interplay between IL6 and CRIM1 in thiopurine toxicity was suggested.

Clinically more relevant is the evaluation of the magnitude of the actual decrease in 6-MP DIP (\%) tolerated by patients than mere statistical significance affected by study sample size and biomarker prevalence. Table 1 demonstrates that about one quarters of homozygous-CRIM1 $(27.3 \%, 3 / 11)$ and IL6-and-CRIM1 $(25.0 \%, 2 / 8)$ groups were intolerant less than $25 \%$ of the planed DIP, increasing the risk of thiopurine therapeutic failure and relapse of leukemia. These intolerance levels are comparable to those of the long-known NUDT15 $(29.2 \%=21 / 72)$ and TPMT $(22.2 \%, 2 / 11)$ non-WTs (Table 1) published in the current CPIC guideline. Furthermore, when we raised the DIP cutoff from $25 \%$ to $35 \%$, the quarter proportions of homozygous-CRIM1 and IL6-and-CRIM1 groups went up to $54.6 \%(6 / 11)$ and $87.5 \%(7 / 8)$, respectively, which far exceeded $38.9 \%$ and $33.3 \%$ of NUDT15 (28/72) and TPMT (3/9) non-WTs, respectively. Please notice 
medRxiv preprint doi: https://doi.org/10.1101/2020.07.21.20158931; this version posted July 25, 2020. The copyright holder for this preprint

that only $6.1(7 / 115)$ and $10.5 \%(12 / 115)$ of all WTs were intolerant less than $25 \%$ and $35 \%$ of the planed DIP (Table 1).

\section{Interethnic variabilities in carrier frequencies and molecular phenotypes}

Both NUDT15 and TPMT shows wide inter-ethnic variabilities. Table 2 exhibits interethnic variabilities of the PGx variants and molecular phenotypes of the four thiopurine pharmacogenes computed from the 2504 subjects of the 1000 Genomes Project [9]. NUDT15 non-WT (i.e., IM or PM) is popular in East (22.6\%) and South (13.9\%) Asians but rare in Europeans and Africans $(<1 \%)$. In contrast, TPMT non-WT is popular in Europeans (8.0\%) and Americans (13.3\%) but relatively rare in Asians $(<5.0 \%)$.

Novel PGx variant, CRIM1 rs3821169, demonstrates remarkably high minor allele frequency $(T=0.255)$ and carrier prevalence $(43.7 \%, 220 / 504)$ in East Asians. Table 2 also shows that $6.5 \%$ of East Asians harbor homozygous CRIM1 rs3821169 variant, which can hardly be found in other populations $(<1.0 \%)$. In contrast, IL6 rs 13306435 is widely distributed with the highest carrier frequency of $15.0 \%$ in Americans and 3.0\% among Asian and European populations. It is rare in South Asian and African populations (<1.0\%). The carrier frequency of both IL6-and-CRIM1 variants were $2.0 \%$ and $1.2 \%$ of East Asian and American populations, respectively.

\section{Single- and multi-gene prediction performances of IL6 and CRIM1}

We performed ROC analysis of GVB-based single- and multi-gene models for predicting the last-cycle 6-MP DIP (\%) using 240 both WTs for NUDT15 and TPMT to control their long-known PGx effects. Figure 3 demonstrates that (b) GVB ${ }^{C R I M 1}$ outperformed (a) GVB $^{\text {LL6 }}$ in predicting DIPs at all cutoff levels, probably due to the higher variant frequency of CRIM1 over IL6 in the study population. Two-gene model GVB ${ }^{I L 6, C R I M 1}$ (Fig. 3(c)) 
medRxiv preprint doi: https://doi.org/10.1101/2020.07.21.20158931; this version posted July 25, 2020. The copyright holder for this preprint

consistently outperformed each of the single gene models (GVB ${ }^{L 66}$ and $G V B^{C R I M 1}$ ) at all cutoffs.

For comprehensive evaluation of all PGx interactions among NUDT15, TPMT, IL6, and CRIM1, we performed comprehensive ROC analysis using the whole 320 pediatric ALL patients (Fig. 4). Among the four single-gene model in Figure 4 (a, b, d, e) GVB $^{\text {NUDT15 }}$ outperformed others at all cutoffs, probably due to NUDT15‘s high prevalence and strong metabolic impact of on thiopurine toxicity. Two-gene models (Fig. $4(\mathrm{c}, \mathrm{f})$ ) consistently outperformed each of the corresponding single-gene counterparts, i.e., $\mathrm{AUCs}$ of $\mathrm{GVB}^{\text {NUDT15, TPMT }}>\mathrm{GVB}^{\text {NUT15 }}>\mathrm{GVB}^{\text {TPMT }}$ and of $\mathrm{GVB}^{\text {LL6,CRIM1 }}>\mathrm{GVB}^{\text {CRIM1 }}>\mathrm{GVB}^{\text {LL6 }}$ at all cutoff levels. Three-gene models created by adding IL6 or CRIM1 to the traditional NUDT15 and TPMT model also consistently improved the prediction accuracies (Fig. 4(g, h)). The final four-gene model in Figure 4(i) outperformed all other models in predicting DIPs at all cutoff levels. Moreover, it is worth noting that the ROC curves across eight DIP cutoffs in Figure 4 exhibited 'dose-response relationships', i.e., GVB score's prediction power (measured by AUC) increases as a function of the severity of thiopurine intolerance (measured by DIP). For instance, the final four-gene model's AUC increases as a function of decreasing DIP (\%) (i.e., $A \cup C^{<15 \%}=0.757, \mathrm{AUC}^{<25 \%}=0.748, \mathrm{AUC}^{<35 \%}=$ $0.711, \mathrm{AUC}^{<45 \%}=0.716, \mathrm{AUC}^{<60 \%}=0.646$, and $\mathrm{AUC}^{<80 \%}=0.592$ in a descending order, Fig. 4(i)).

\section{Evaluation of clinical validity and utility of star allele and GVB method}

We systematically compared the clinical utility as well as clinical validity of traditional star ${ }^{*}$ ) allele-based and GVB-based methods for preventing thiopurine toxicity. Table 3 demonstrates the measures of clinical validity, i.e., sensitivity, specificity, PPV, and NPV, and of potential population impact (or clinical utility), i.e., RR, PAF, NNT, and NNG along with pharmacogenetic association (odds ratio (OR) of different prediction modes [14]. 
medRxiv preprint doi: https://doi.org/10.1101/2020.07.21.20158931; this version posted July 25, 2020. The copyright holder for this preprint

Because no designated star allele for IL6 or CRIM1 is available yet, star allele-based molecular phenotyping was not applicable for these novel genes. We used GVB method. GVB $^{\text {NUDT15,TPMT }}$ slightly outperformed STAR ${ }^{\text {NUDT15,TPMT, }}$, the classical star $\left(^{*}\right)$ allele-based molecular phenotyping (Table $3(a, b))$. Three-gene models (i.e., $\mathrm{GVB}^{\text {NUDT15,TPMT,IL6 }}$ and GVB ${ }^{\text {NUDT15,TPMT,CRIM1* }}$ in Table 3(c) and (d)) also outperformed the two-gene models. Four-gene interplay model, GVB ${ }^{N U D T 15, T P M T, I L 6, C R I M 1^{\wedge}(C R I M 1, I L 6)}$, presented the best performances for all of the eight measures of clinical validity and potential population impact (except specificity) (marked in bold numbers in Table 3(g)).

Addition of IL6 and CRIM1 to create the final four-gene model integrating both common and rare alleles markedly improved PAF from 0.36 to 0.58 as well as RR (3.29 to 5.73 ) and OR (4.21 to 8.06$)$. PAF is the proportion of events that is attributed to the PGx risk factor or the maximum percentage of cases that can be prevented if individuals who test positive for the PGx variants receive different treatments. Of the 44 adverse events (DIP<25\%), it might have prevented eight more patients from 23 to 31 than traditional star $\left(^{*}\right)$ allele-based method (STAR ${ }^{\text {NUDT15,TPMT }}$, Table 3(a) vs. (f)).

The number needed to genotype (NNG) is the number of patients that has to be genotyped to prevent one patient from having an adverse event. The NNG of 20 and

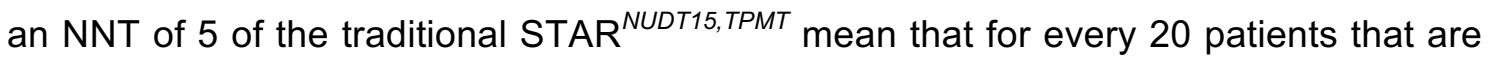
genotyped, 5 patients will learn that they test positive and need to receive alternative treatment to prevent adverse event (DIP $<25 \%)$ in one. Adding IL6 and CRIM1 to the traditional NUDT15 and TPMT testing to create GVB $^{\text {NUDT15,TPMT, IL6,CRIM1^(CRIM1,L66) }}$ may require only 12.5 patients ( $37.5 \%$ improvement of NNG) to be genotyped to return 3.7 test-positive patients $(26.0 \%$ improvement of NNT) receiving alternative treatment to prevent adverse event in one (Table $2(\mathrm{~g})$ ). 
medRxiv preprint doi: https://doi.org/10.1101/2020.07.21.20158931; this version posted July 25, 2020. The copyright holder for this preprint

\section{Discussion}

Interplay between IL6 and CRIM1 variants on thiopurine-induced hematological toxicity was investigated in 320 pediatric ALL patients. IL6 has been known to behavior as a neutrophil protector. There was an inverse correlation between IL6 levels and neutrophil apoptosis $(r=(-) 0.855$ and $p<0.007)$, but this was not the case for other cytokines. The antiapoptotic effect of osteomyelitis sera was reversed with anti-IL6 antibodies and was reproduced with recombinant human IL6 [28]. Decreased neutrophil counts have been reported in trials of tocilizumab in rheumatoid arthritis patients $[29,30]$. Tocilizumab is a recombinant monoclonal $\mathrm{Ab}$ that binds to soluble and membrane-bound IL-6R (Interleukin 6 Receptor) and inhibits IL6 signaling pathways [31, 32]. Preclinical studies suggest that the reduction in neutrophil count may result from increased margination of circulating neutrophils into the bone marrow rather than from the drug-induced neutropenia observed with myelotoxic drugs [33, 34].

CRIM1 (Cysteine-Rich Transmembrane BMP Regulator 1) is a cell-surface transmembrane protein that resembles developmentally important proteins which are known to interact with bone morphogenetic proteins (BMPs). A role of CRIM1 in drug resistance has been suggested by previous studies $[35,36]$ revealing that the level of mRNA expression of CRIM1 is high in resistant leukemic cells. This affects the levels of BMPs, suggesting that CRIM1 regulates the growth and differentiation of hematopoietic cells. It is suggested that the interplay of IL6 and CRIM1 on thiopurine-induced hematological toxicity may be a pharmacodynamic effect on adverse reaction while the long-known NUDT15 and TPMT are pharmacokinetic enzymes for metabolizing thiopurines.

Seven $(6.1 \%)$ of the 115 all-WT patients still suffered from thiopurine toxicity. Supplementary Table S1 lists further candidate variants determined by analyzing the all WTs $(N=115, p<0.05$ by one-sided Student $T$-test). Of the three carriers of FSIP2 
medRxiv preprint doi: https://doi.org/10.1101/2020.07.21.20158931; this version posted July 25, 2020. The copyright holder for this preprint

rs191083003, two $(66.7 \%)$ exhibited DIP $<25 \%(8.82,21.88$, and $48.54 \%, N=3)$. We found one more FSIP2 rs191083003 carrier among the homozygous-CRIM group, who exhibited the lowest DIP of $6.94 \%$ among the whole 320 ALL cohort. The low frequency $(1.25 \%, 4 / 320)$ of FSIP2 rs191083003 prohibited any conclusion but to await further elucidation. Overall, the interplay of IL6 and CRIM1 along with the long-known NUDT15 and TPMT improved PAF from $36.4 \%$ to $58.2 \%$ by considering PGx variants only in an East Asian cohort of pediatric ALL $(N=320)$. The quantitative analytic approach of the present study may be applied to other ethnic groups for further discovery and evaluation of thiopurine-toxicity pharmacogenomics.

Americans show the highest allele frequency of IL6 rs13306435 (A=0.078) among all ethnic groups (Global $A=0.020$, the 1000 Genomes Project, Phase 3 [9]). This high inter-ethnic variability may partially explain why rs13306435 has not yet been discovered as a biomarker for thopurine toxicity. Current research is mostly biased towards Europeans [37]. NUDT15 rs116855232 variant, which was recently discovered in the Korean population as a strong predictor of thopurine toxicit [3], shows the highest allele frequency in East Asians ( $T=0.095)$ among all ethnic groups (Global $T=0,040$ ). Pharmacogenes by definition, unlike pathogenic disease genes, do not have an overt phenotype unless exposed to drugs. The absence of detrimental phenotypic effect from phrmacogenes may have permitted wide inter-ethnic variability and/or diversity across different ethnic groups under various evolutionary selection pressures.

The CPIC guideline for thiopurine treatment for pediatric ALL is based on star $\left(^{*}\right)$ allele-based haplotypes with designated molecular phenotypes of NUDT15 and TPMT $[6,7]$. However, CPIC does not provide general standard rules of how to combine multi-gene interactions of the categorically classified star-alleles. Novel genes like IL6 and CRIM1 have no designated star alleles nor molecular phenotypes yet. Quantitative GVB method has benefits over categorical star allele-based approaches. GVB 
medRxiv preprint doi: https://doi.org/10.1101/2020.07.21.20158931; this version posted July 25, 2020. The copyright holder for this preprint

quantitates single- or multi-gene PGx burden of common, rare, and novel variants into a single score to provide a comprehensive framework for further PGx discovery and evaluation of many gene interactions. A conventional single variant-based association test of rare variants requires infeasible magnitude of sample sizes [38], but approaches that aggregate common, rare, and novel variants jointly will substantially reduce a required effective sample sizes [39]. In contrast to traditional haplotyping-based method, GVB assigns a gene-level score for each pharmacogene without using population data and hence to enable unbiased PGx method especially for under-studied subpopulations.

\section{Acknowledgements}

This research was supported by a grant (16183MFDS541) from Ministry of Food and Drug Safety in 2019.

\section{Conflict of Interest}

The authors declare that they have no competing interests.

\section{Data availability}

The data that support the findings of this study are available on request from the corresponding author.

\section{Ethical statement}

The study was approved by the AMC Review Boards, the SMC Review Boards, and the SNUH Review Boards. Informed written consents for blood sampling and analyses were obtained from all participants. 
medRxiv preprint doi: https://doi.org/10.1101/2020.07.21.20158931; this version posted July 25, 2020. The copyright holder for this preprint (which was not certified by peer review) is the author/funder, who has granted medRxiv a license to display the preprint in perpetuity.

\section{References}

1. Schaeffeler E, Jaeger SU, Klumpp V, Yang JJ, Igel S, Hinze L, et al. Impact of NUDT15 genetics on severe thiopurine-related hematotoxicity in patients with European ancestry. Genet Med. 2019;21(9):2145-50.

2. Yang, Jun J., et al. "Inherited NUDT15 variant is a genetic determinant of mercaptopurine intolerance in children with acute lymphoblastic leukemia." Journal of clinical oncology 33.11 (2015): 1235.

3. Yang S-K, Hong M, Baek J, Choi H, Zhao W, Jung $\mathrm{Y}$ et al. A common missense variant in NUDT15 confers susceptibility to thiopurine-induced leukopenia. Nature Genetics 2014; 46: 1017-1020.

4. Moriyama, Takaya, et al. "NUDT15 polymorphisms alter thiopurine metabolism and hematopoietic toxicity." Nature genetics 48.4 (2016): 367-373.

5. Relling MV, Klein TE. CPIC: Clinical Pharmacogenetics Implementation Consortium of the Pharmacogenomics Research Network. Clin Pharmacol Ther. 2011;89(3):464-7.

6. Relling MV, Gardner EE, Sandborn WJ, Schmiegelow K, Pui CH, Yee SW, et al. Clinical pharmacogenetics implementation consortium guidelines for thiopurine methyltransferase genotype and thiopurine dosing: 2013 update. Clin Pharmacol Ther. 2013;93(4):324-5.

7. Relling MV, Schwab M, Whirl-Carrillo M, Suarez-Kurtz G, Pui CH, Stein CM, et al. Clinical Pharmacogenetics Implementation Consortium Guideline for Thiopurine Dosing Based on TPMT and NUDT15 Genotypes: 2018 Update. Clin Pharmacol Ther. 2019;105(5):1095-105.

8. Park Y, Kim H, Seo H, Choi JY, Ma Y, Yun S, Min BJ, Seo ME, Yoo KH, Kang HJ, Im HJ, Kim JH. A CRIM1 genetic variant is associated with thiopurine-induced neutropenia in leukemic patients with both wild-type NUDT15 and TPMT. Journal of Translational Medicine (in press)

9. Genomes Project C, Auton A, Brooks LD, Durbin RM, Garrison EP, Kang HM, et al. A global reference for human genetic variation. Nature. 2015;526(7571):68-74.

10. Lee K. H., Baik S. Y., Lee S. Y., Park C. H., Park P. J., Kim J. H. (2016). Genome sequence variability predicts drug precautions and withdrawals from the market. PLoS ONE 11, e0162135-0162115. 10.1371/journal.pone.0162135

11. Park Y, Kim H, Choi JY, Yun S, Min BJ, Seo ME, et al. Star Allele-Based Haplotyping versus Gene-Wise Variant Burden Scoring for Predicting 6Mercaptopurine Intolerance in Pediatric Acute Lymphoblastic Leukemia Patients. Front Pharmacol. 2019;10:654.

12. Park $\mathrm{Y}$, Seo H, Ryu BY, Kim JH. Gene-wise variant burden and genomic characterization of nearly every gene. Pharmacogenomics (in press)

13. Park J, Lee SY, Baik SY, Park CH, Yoon JH, Ryu BY, Kim JH. Gene-wise burden 
medRxiv preprint doi: https://doi.org/10.1101/2020.07.21.20158931; this version posted July 25, 2020. The copyright holder for this preprint (which was not certified by peer review) is the author/funder, who has granted medRxiv a license to display the preprint in perpetuity. It is made available under a CC-BY-NC-ND 4.0 International license.

of coding variants correlates to noncoding pharmacogenetic risk variants. Int $\mathrm{J}$ Mol Sci. 2020 Apr 27;21(9). pii: E3091

14. E C M Tonk, D Gurwitz, A-H Maitland-van der Zee, and A C J W Janssens. Assessment of pharmacogenetic tests: presenting measures of clinical validity and potential population impact in association studies. Pharmacogenomics J 2017 Jul; 17(4): 386-392

15. Lange BJ, Bostrom BC, Cherlow JM, Sensel MG, La MK, Rackoff W, et al. Doubledelayed intensification improves event-free survival for children with intermediaterisk acute lymphoblastic leukemia: a report from the Children's Cancer Group. Blood. 2002;99(3):825-33.

16. Matloub Y, Lindemulder S, Gaynon PS, Sather H, La M, Broxson E, et al. Intrathecal triple therapy decreases central nervous system relapse but fails to improve event-free survival when compared with intrathecal methotrexate: results of the Children's Cancer Group (CCG) 1952 study for standard-risk acute lymphoblastic leukemia, reported by the Children's Oncology Group. Blood. 2006;108(4):1165-73.

17. Maloney KW, Devidas M, Wang C, Mattano LA, Friedmann AM, Buckley $\mathrm{P}$, et al. Outcome in Children With Standard-Risk B-Cell Acute Lymphoblastic Leukemia: Results of Children's Oncology Group Trial AALL0331. J Clin Oncol. 2020;38(6):602-12.

18. Nachman J, Sather HN, Cherlow JM, Sensel MG, Gaynon PS, Lukens JN, et al. Response of children with high-risk acute lymphoblastic leukemia treated with and without cranial irradiation: a report from the Children's Cancer Group. J Clin Oncol. 1998;16(3):920-30.

19. Rhee ES, Kim H, Kang SH, Yoo JW, Koh KN, Im HJ, et al. Outcome and Prognostic Factors in Pediatric Precursor T-Cell Acute Lymphoblastic Leukemia: A Single-Center Experience. Clinical Pediatric Hematology-Oncology. 2018;25(2):116-27.

20. Kim H, Kang HJ, Kim HJ, Jang MK, Kim NH, Oh Y, et al. Pharmacogenetic analysis of pediatric patients with acute lymphoblastic leukemia: a possible association between survival rate and ITPA polymorphism. PLoS One. 2012;7(9):e45558.

21. Kim H, Seo H, Park Y, Min BJ, Seo ME, Park KD, et al. APEX1 Polymorphism and Mercaptopurine-Related Early Onset Neutropenia in Pediatric Acute Lymphoblastic Leukemia. Cancer Res Treat. 2018;50(3):823-34.

22. Stephens, Matthew, and Paul Scheet. "Accounting for decay of linkage disequilibrium in haplotype inference and missing-data imputation." The American Journal of Human Genetics 76.3 (2005): 449-462.

23. Stephens, Matthew, Nicholas J. Smith, and Peter Donnelly. "A new statistical method for haplotype reconstruction from population data." The American Journal of Human Genetics 68.4 (2001): 978-989

24. Ng PC. SIFT: predicting amino acid changes that affect protein function. Nucleic 
medRxiv preprint doi: https://doi.org/10.1101/2020.07.21.20158931; this version posted July 25, 2020. The copyright holder for this preprint (which was not certified by peer review) is the author/funder, who has granted medRxiv a license to display the preprint in perpetuity.

Acids Research 2003; 31: 3812-3814.

25. Fawcett, Tom. "An introduction to ROC analysis." Pattern recognition letters 27.8 (2006): 861-874.

26. Robin, Xavier, et al. "pROC: an open-source package for R and S+ to analyze and compare ROC curves." BMC bioinformatics 12.1 (2011): 77.

27. Youden, William J. "Index for rating diagnostic tests." Cancer 3.1 (1950): 32-35.

28. Asensi, Víctor, et al. "In vivo interleukin-6 protects neutrophils from apoptosis in osteomyelitis." Infection and immunity 72.7 (2004): 3823-3828.

29. Schiff MH, Kremer JM, Jahreis A. et al. Integrated safety in tocilizumab clinical trials. Arthritis Res Ther 2011;13:1-13.

30. Gabay C, Emery P, van Vollenhoven R. et al. Tocilizumab monotherapy versus adalimumab monotherapy for treatment of rheumatoid arthritis (ADACTA): a randomised, double-blind, controlled phase 4 trial. Lancet 2013;381:1541-50.

31. Mihara M, Kasutani K, Okazaki M. et al. Tocilizumab inhibits signal transduction mediated by both mIL-6R and sIL-6R, but not by the receptors of other members of IL-6 cytokine family. Int Immunopharmacol 2005;5:1731-40.

32. Nishimoto N, Terao K, Mima T. et al. Mechanisms and pathologic significances in increase in serum interleukin-6 (IL-6) and soluble IL-6 receptor after administration of an anti-IL-6 receptor antibody, tocilizumab, in patients with rheumatoid arthritis and Castleman disease. Blood 2008;112:3959-64. [PubMed] [Google Scholar]

33. Suwa T, Hogg JC, English D, van Eeden SF. Interleukin-6 induces demargination of intravascular neutrophils and shortens their transit in marrow. Am J Physiol Heart Circ Physiol 2000;279:H2954-60. [PubMed] [Google Scholar]

34. Hashizume M, Higuchi Y, Uchiyama Y, Mihara M. IL-6 plays an essential role in neutrophilia under inflammation. Cytokine 2011;54:92-9. [PubMed] [Google Scholar]

35. Prenkert M, Uggla B, Tidefelt $U$, Strid H. CRIM1 is expressed at higher levels in drug-resistant than in drug-sensitive myeloid leukemia HL60 cells. Anticancer Res. 2010;30(10):4157-61.

36. Ziliak D, Gamazon ER, Lacroix B, Kyung Im H, Wen Y, Huang RS. Genetic variation that predicts platinum sensitivity reveals the role of miR-193b* in chemotherapeutic susceptibility. Mol Cancer Ther. 2012;11(9):2054-61.

37. Sirugo G, Williams SM, Tishkoff SA. The Missing Diversity in Human Genetic Studies. Cell 2019; 177: 26-31.

38. Bansal V, Libiger O, Torkamani A, Schork NJ. Statistical Analysis Strategies for Association Studies Involving Rare Variants. Nat Rev Genet 2010 Nov; 11(11): 773-785. 
medRxiv preprint doi: https://doi.org/10.1101/2020.07.21.20158931; this version posted July 25, 2020. The copyright holder for this preprint (which was not certified by peer review) is the author/funder, who has granted medRxiv a license to display the preprint in perpetuity. It is made available under a CC-BY-NC-ND 4.0 International license .

39. Witte. Rare Genetic Variants and Treatment Response: Sample Size and Analysis Issues. Stat Med. 2012;31(25):3041-3050. 
medRxiv preprint doi: https://doi.org/10.1101/2020.07.21.20158931; this version posted July 25,2020 . The copyright holder for this preprint (which was not certified by peer review) is the author/funder, who has granted medRxiv a license to display the preprint in perpetuity. It is made available under a CC-BY-NC-ND 4.0 International license.

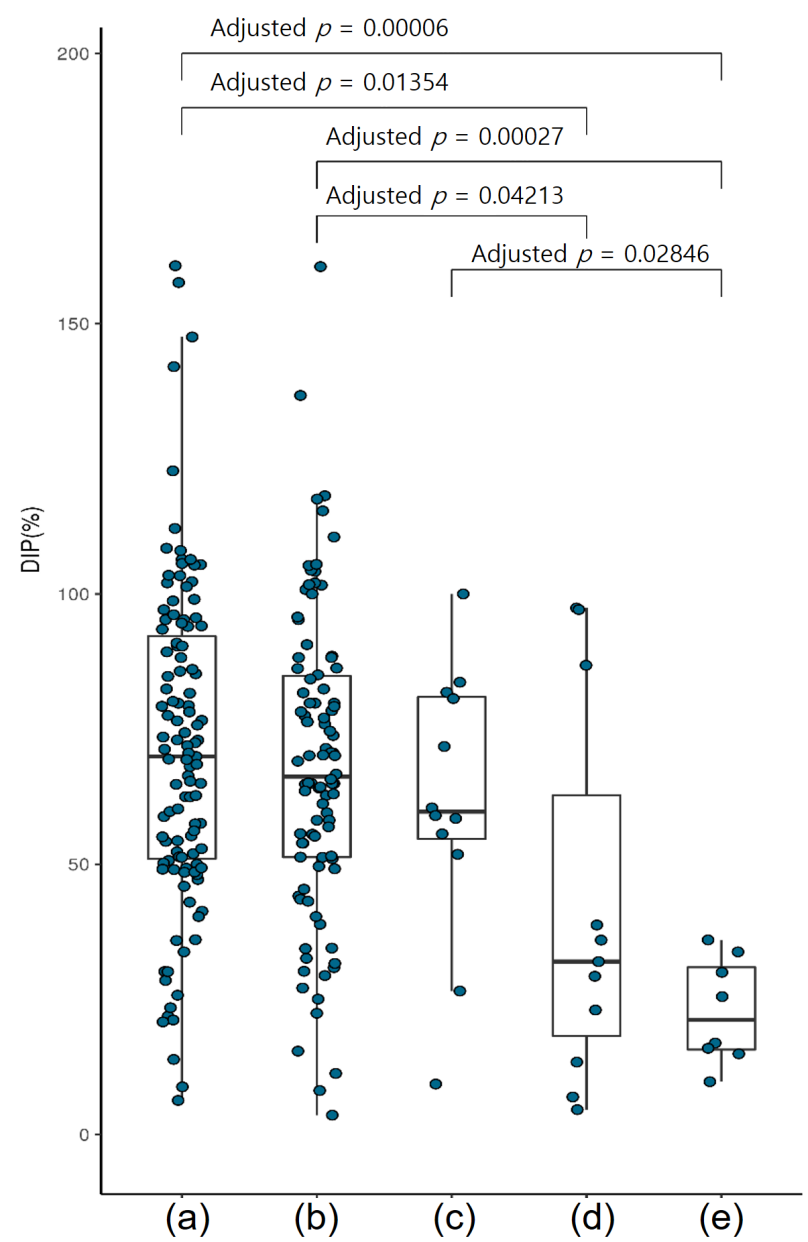

(a) Non-carrier of CRIM1 rs3821169 nor IL6 rs13306435 ( $N=115,47.92 \%$, All WTs in Table 1 and Fig. 2)

(b) Carrier of CRIM1 rs3821169 heterozygote only $(N=94,39.17 \%)$

(c) Carrier of IL6 rs13306435 heterozygote only $(N=12,5.00 \%)$

(d) Carrier of CRIM1 rs3821169 homozygote only ( $N=11,4.38 \%)$

(e) Carrier of both IL6 rs13306435 and CRIM1 rs3821169 (hetero- or homozygote) $(N=8,3.33 \%)$

Figure 1. Distribution of the tolerated last-cycle 6-MP DIPs (\%) of CRIM1 rs3821169- and/or IL6 rs13306435-variant carrier vs. non-carrier subgroups among 240 pediatric ALL subjects with both NUDT15 and TPMT WTs.

Of the 320 pediatric ALL patients, we excluded 80 carriers of either NUDT15 or TPMT variant to obtain 240 both NUDT15-and-TPMT WT subjects. Both (a) non-carrier group of CRIM1 rs3821169 nor IL6 rs13306435 ( $N=115,47.92 \%$, i.e., 'All WTs' in Table 1 and Fig. 2) and (b) carrier group of CRIM1 rs3821169 heterozygote only ( $N=94,39.17 \%)$ showed significantly higher thiopurine tolerance than carrier groups of (d) CRIM1 rs3821169 homozygote $(N=11,4.38 \%)$ (adj. $p<0.05$, posthoc Tukey) and of (e) both IL6 rs13306435 and CRIM1 rs3821169 (N=8, 3.33\%) (adj. $p<0.0005$, posthoc Tukey) by one-way ANOVA ( $p=0.0001)$. (c) Carrier group of IL6 rs 13306435 heterozygote variant only $(N=12,5.00 \%)$ also showed significantly higher thiopurine intolerance than (c) that of both IL6 and CRIM1 hetero/homozygote (adj. $p<0.05$, posthoc Tukey).

No carrier of IL6 homozygote was found and only one subject carried both IL6 heterozygote and CRIM1 homozygote variants (DIP $=9.7 \%$ ). Thiopurine intolerance was measured by the lastcycle 6-MP DIP(\%) among the 240 pediatric ALL patients with both NUDT15 and TPMT wilde type genes to control their effect on thiopurine intolerance. ALL: Acute Lymphoblastic Leukemia, WT: Wild Type, DIP (\%): Dose Intensity Percentage, ${ }^{*} p<0.05$ and ${ }^{* *} p<0.01$, post-hoc Tukey test after one-way ANOVA 
medRxiv preprint doi: https://doi.org/10.1101/2020.07.21.20158931; this version posted July 25,2020 . The copyright holder for this preprint (which was not certified by peer review) is the author/funder, who has granted medRxiv a license to display the preprint in perpetuity. It is made available under a CC-BY-NC-ND 4.0 International license .

\section{Total ALL Patients with 6-MP Maintenance Therapy} $N=320, D I P=61.93 \pm 31.44 \%$

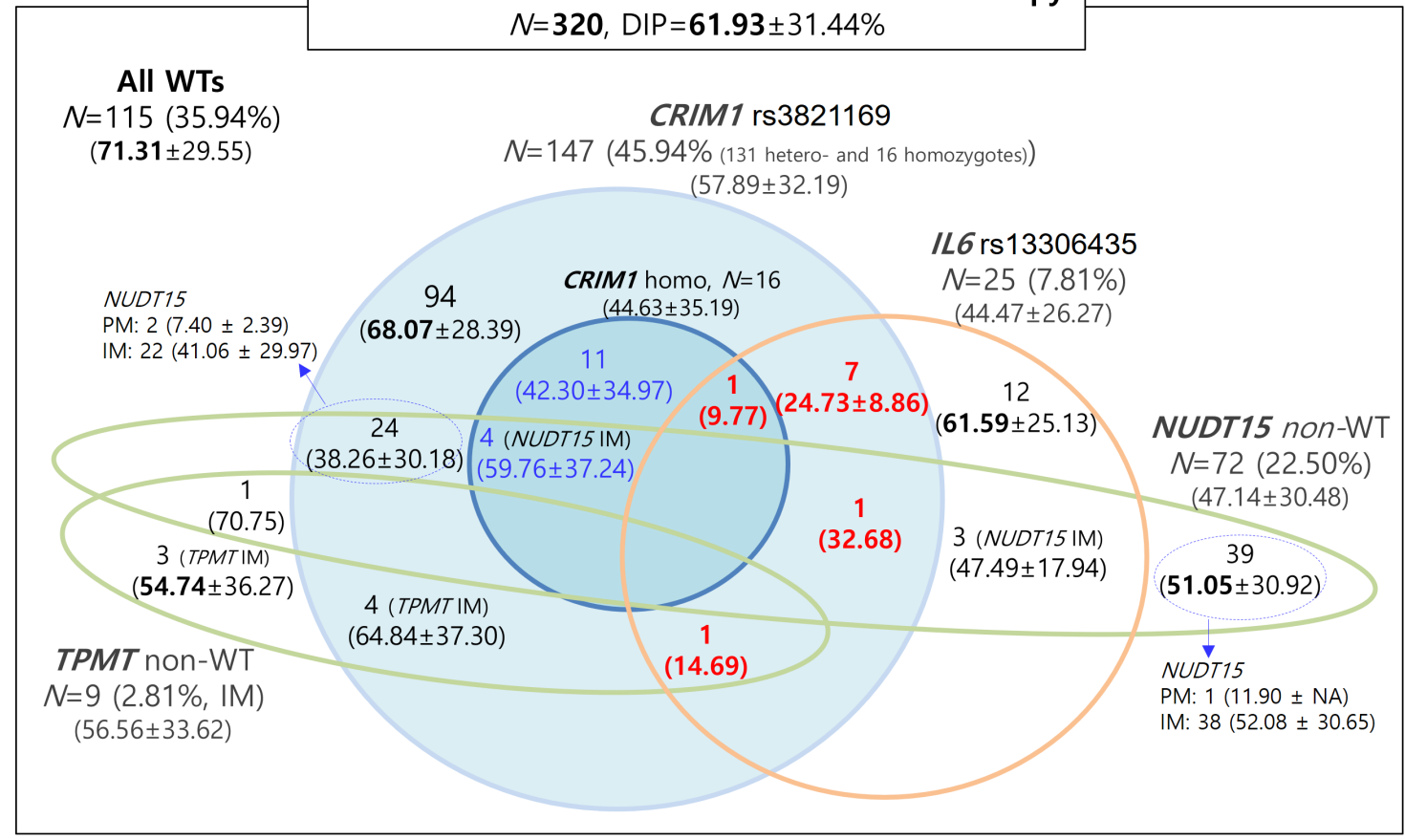

Figure 2. Distribution of the last-cycle 6-MP DIP of pediatric ALL patients according to NUDT15, TPMT, CRIM1 and IL6 pharmacogenetic subgroups $(\mathrm{N}=320)$. Green circles depict NUDT15 and TPMT metabolizer phenotypes and blue and orange circles represent CRIM1 rs3821169 and $L 6$ rs 13306435 genotype subgroups, respectively. Of the 320 patients, 115 with no pharmacogenetic variants exhibited higher 6-MP DIPs $(71.31 \%)$ than 72 NUDT15 $(47.14 \%)$, 9 TPMT (56.56\%), 147 CRIM1 (57.89\%), and 25 IL6 (DIP=44.47\%) non-WTs. Subjects with both CRIM1 and IL6 variants ( $N=10,3.13 \%)$ exhibited the lowest DIPs $(9.77 \sim 32.68 \%$, in red numbers). Numbers are number of subjects and 6-MP DIPs (mean \pm S.D.). ALL: Acute Lymphoblastic Leukemia, WT: Wild Type, non-WT: non wild-type, i.e., poor or intermediate metabolizers for NUDT15 and TPMT, DIP: Dose Intensity Percentage. 
medRxiv preprint doi: https://doi.org/10.1101/2020.07.21.20158931; this version posted July 25,2020 . The copyright holder for this preprint (which was not certified by peer review) is the author/funder, who has granted medRxiv a license to display the preprint in perpetuity.

(a) GVB/LG

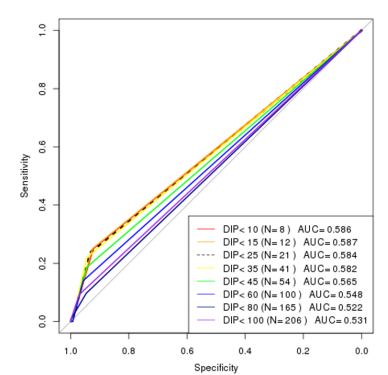

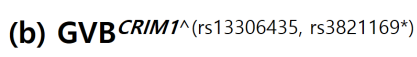

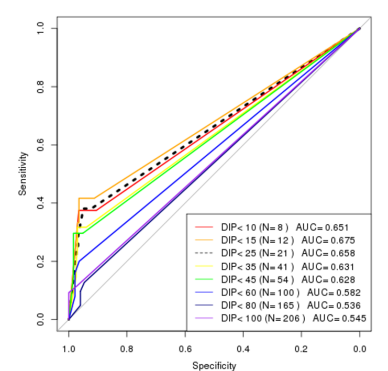

(c) GVB $/ L 6, C R I M 1^{\wedge}\left(\right.$ rs 13306435, rs $\left.3821169^{*}\right)$

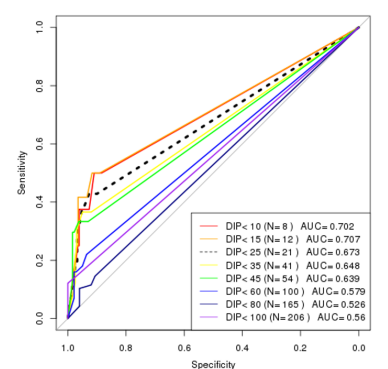

Figure 3. ROC analysis of IL6, CRIM1, and their combined prediction accuracies for thiopurine intolerance among pediatric ALL subjects with both wild-type NUDT15 and TPMT genes $(\mathrm{N}=240)$.

Single-gene prediction models of (a) IL6 and (b) CRIM1 were highly outperformed by (c) the twogene combined model for predicting thiopurine intolerance at all DIP levels. We excluded 80 among the total of 320 subjects to control the effects of the well-established NUDT15 and TPMT genes and performed ROC analysis for the 240 subjects with both wild-type NUDT15 or TPMT genes. Prediction accuracies were measured across 8 cutoff levels for the last-cycle 6-MP DIP (\%) $(\leq 10 \%, \leq 15 \%, \leq 25 \%, \leq 35 \%, \leq 45 \%, \leq 60 \%, \leq 80 \%$, and $\leq 100 \%)$ in terms of AUC. DIP (\%): Dose Intensity Percentage, AUC: Area Under the ROC (Receiver Operating Characteristics) Curve, GVB: Gene-wise Variant Burden, GVB ${ }^{\text {CRIM1^}^{\wedge}\left(r s 13306435, r s 3821169^{*}\right)}$ : GVB of CRIM1 dependent on IL6 rs13306435 or CRIM1 rs3821169 homozygote . 
medRxiv preprint doi: https://doi.org/10.1101/2020.07.21.20158931; this version posted July 25,2020 . The copyright holder for this preprint (which was not certified by peer review) is the author/funder, who has granted medRxiv a license to display the preprint in perpetuity. It is made available under a CC-BY-NC-ND 4.0 International license .

(a) GVBNUDT15

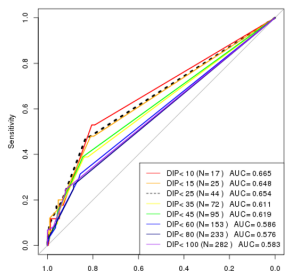

(d) $\mathrm{GVB}^{\mathrm{s} / \mathrm{L} 6}$

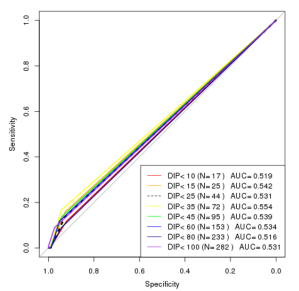

(g) GVBNUDT15, TPMT, IL6

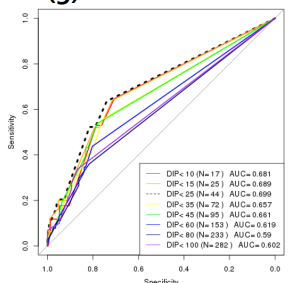

(b) GVB ${ }^{T P M T}$

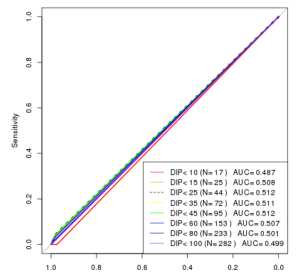

(e) GVB CRIM1^(rss13306435, rs3821169*)

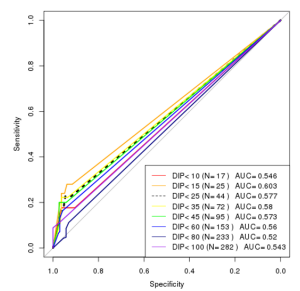

(h) GVBNUDT15, TPMT, CRIM1^(rs13306435, rs3821169^)

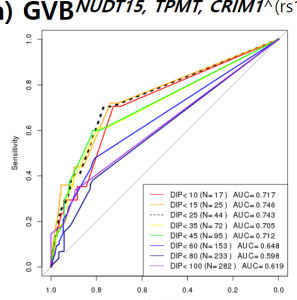

(c) GVBNUDT15, TPMT

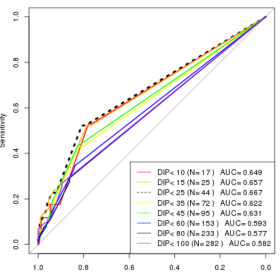

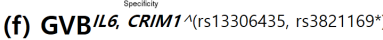

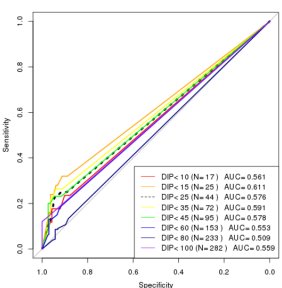

(i) GVBNUDT15, TPMT, IL6, CRIM1^(rs13306435, rs3821169*)

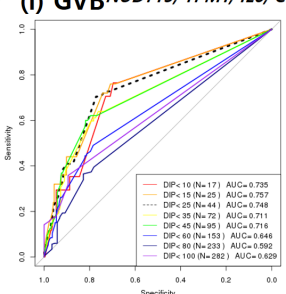

Figure 4. Prediction accuracy profile of single- and multi-gene models for thiopurine intolerance in the whole pediatric ALL subjects $(\mathbf{N}=320)$. Single-gene prediction models of (a) NUDT15 and (b) TPMT were outperformed by (c) the two-gene combined model and of (d) IL6 and (e) CRIM by (f) IL6-CRIM1 combined model. Three-gene models of NUDT15, TPMT and (g) IL6 and (h) CRIM1 were outperformed by (i) all four-gene combined model. Overall the final (i) four-gene combined model outperformed other models for predicting thiopurine intolerance at all DIP levels in pediatric ALL subjects $(\mathrm{N}=320)$. AUCs for predicting the last-cycle 6-MP DIP (\%) were measured at 8 cutoff levels of $(\leq 10 \%, \leq 15 \%, \leq 25 \%, \leq 35 \%, \leq 45 \%, \leq 60 \%, \leq 80 \%$, and $\leq 100 \%)$. ALL: Acute Lymphoblastic Leukemia, DIP: Dose Intensity Percentage, AUC: Area Under the Receiver Operating Characteristics Curve, GVB: Gene-wise Variant Burden. 
Table 1. Clinical characteristics of 320 pediatric ALL patients with 6-MP maintenance therapy according to their pharmacogenetic subgroups of NUDT15, TPMT, CRIM1 and IL6 genes.

\begin{tabular}{|c|c|c|c|c|c|c|c|c|c|c|c|c|c|c|}
\hline \multirow[b]{2}{*}{ Characteristic } & \multirow{2}{*}{\multicolumn{2}{|c|}{$\begin{array}{c}\begin{array}{c}\text { All WTs } \\
\mathbf{N}=\mathbf{1 1 5}\end{array} \\
\text { WTs for all of } \\
N U D T 15, T P M T, \\
C R I M 1, \text { and } I L 6\end{array}$}} & \multicolumn{4}{|c|}{$\begin{array}{c}\text { NUDT15 or TPMT Non-WT } \\
\qquad=80^{\dagger}\end{array}$} & \multicolumn{8}{|c|}{$\begin{array}{l}\text { NUDT15 and TPMT both WTs } \\
\qquad N=125\end{array}$} \\
\hline & & & \multicolumn{2}{|c|}{$\begin{array}{c}\text { NUDT15 non- } \\
\mathrm{WT}^{\dagger}\end{array}$} & \multicolumn{2}{|r|}{$\begin{array}{l}\text { TPMT non- } \\
\mathrm{WT}^{\dagger}\end{array}$} & \multicolumn{2}{|c|}{$\begin{array}{c}\text { CRIM1 } \\
\text { rs3821169 } \\
\text { heterozygote } \\
\text { only }\end{array}$} & \multicolumn{2}{|c|}{$\begin{array}{c}\text { IL6 } \\
\text { rs13306435 } \\
\text { heterozygote } \\
\text { only }\end{array}$} & \multicolumn{2}{|c|}{$\begin{array}{c}\text { CRIM1 } \\
\text { rs3821169 } \\
\text { homozygote } \\
\text { only } \\
\end{array}$} & \multicolumn{2}{|c|}{$\begin{array}{l}\text { IL6 and } \\
\text { CRIM1 hetero- } \\
\text { or homozygote }\end{array}$} \\
\hline No. of subjects & \multicolumn{2}{|c|}{$115(35.94 \%)$} & \multicolumn{2}{|r|}{$72(22.50 \%)$} & \multicolumn{2}{|r|}{$9(2.81 \%)$} & \multicolumn{2}{|c|}{$94(39.17 \%)$} & \multicolumn{2}{|c|}{$12(5.00 \%)$} & & $1(4.38 \%)$ & \multicolumn{2}{|c|}{$8(3.33 \%)$} \\
\hline $\begin{array}{l}\text { Age, median (range, } \\
\text { year) }\end{array}$ & \multicolumn{2}{|c|}{$5.3(1.2-19.4)$} & \multicolumn{2}{|c|}{$4.6(1.7-15.8)$} & \multicolumn{2}{|c|}{$3.6(1.3-14.8)$} & \multicolumn{2}{|c|}{$5.7(1.1-17.0)$} & \multicolumn{2}{|c|}{$5.1(2.4-17.0)$} & 5.9 & $(2.8-21.8)$ & \multicolumn{2}{|c|}{$3.8(1.7-7.9)$} \\
\hline \multicolumn{15}{|l|}{ Sex } \\
\hline Male & & 58 & & 43 & & 6 & & 63 & & 8 & & 7 & & 1 \\
\hline Female & & 57 & & 29 & & 3 & & 31 & & 4 & & 4 & & 7 \\
\hline \multicolumn{15}{|l|}{ Risk group } \\
\hline Standard-risk & & 73 & & 46 & & 4 & & 59 & & 8 & & 8 & & 4 \\
\hline High-risk & & 42 & & 26 & & 5 & & 35 & & 4 & & 3 & & 4 \\
\hline \multicolumn{15}{|c|}{ Last-cycle 6-MP dose, $\mathrm{mg} / \mathrm{m} 2 / \mathrm{day}$} \\
\hline$\sim 10$ & 2 & $(1.7 \%)$ & $\overline{9}$ & $(12.5 \%)$ & 0 & $(0.0 \%)$ & 2 & $(2.1 \%)$ & 1 & $(8.3 \%)$ & 2 & $(18.2 \%)$ & 1 & $(12.5 \%)$ \\
\hline $10 \sim 15$ & 1 & $(0.9 \%)$ & 3 & $(4.2 \%)$ & 1 & $(11.1 \%)$ & 1 & $(1.1 \%)$ & 0 & $(0.0 \%)$ & 1 & $(9.1 \%)$ & 1 & $(12.5 \%)$ \\
\hline $15 \sim 25$ & 4 & $(3.5 \%)$ & 9 & $(12.5 \%)$ & 1 & $(11.1 \%)$ & 2 & $(2.1 \%)$ & 0 & $(0.0 \%)$ & 1 & $(9.1 \%)$ & 2 & $(25.0 \%)$ \\
\hline $25 \sim 35$ & 5 & $(4.4 \%)$ & 7 & $(9.7 \%)$ & 1 & $(11.1 \%)$ & 9 & $(9.6 \%)$ & 1 & $(8.3 \%)$ & 2 & $(18.2 \%)$ & 3 & $(37.5 \%)$ \\
\hline $35 \sim 45$ & 5 & $(4.4 \%)$ & 9 & $(12.5 \%)$ & 1 & $(11.1 \%)$ & 5 & $(5.3 \%)$ & 0 & $(0.0 \%)$ & 2 & $(18.2 \%)$ & 1 & $(12.5 \%)$ \\
\hline $45 \sim 60$ & 26 & $(22.6 \%)$ & 11 & $(15.3 \%)$ & 1 & $(11.1 \%)$ & 16 & $(17.0 \%)$ & 4 & $(33.3 \%)$ & 0 & $(0.0 \%)$ & 0 & $(0.0 \%)$ \\
\hline $60 \sim 80$ & 31 & $(27.0 \%)$ & 14 & $(19.4 \%)$ & 2 & $(22.2 \%)$ & 32 & $(34.0 \%)$ & 2 & $(16.7 \%)$ & 0 & $(0.0 \%)$ & 0 & $(0.0 \%)$ \\
\hline $80 \sim 100$ & 23 & $(20.0 \%)$ & 7 & $(9.7 \%)$ & 1 & $(11.1 \%)$ & 13 & $(13.8 \%)$ & 4 & $(33.3 \%)$ & 3 & $(27.3 \%)$ & 0 & $(0.0 \%)$ \\
\hline $100 \sim$ & 18 & $(15.7 \%)$ & 3 & $(4.2 \%)$ & 1 & $(11.1 \%)$ & 14 & $(14.9 \%)$ & 0 & $(0.0 \%)$ & 0 & $(0.0 \%)$ & 0 & $(0.0 \%)$ \\
\hline Total & 11 & $(100.0 \%)$ & 72 & $(100.0 \%)$ & 9 & $(100.0 \%)$ & 94 & $(100.0 \%)$ & 12 & $(100.0 \%)$ & 11 & $(100.0 \%)$ & & $(100.0 \%)$ \\
\hline
\end{tabular}

${ }^{\mp}$ One subject harbored non-WTs for both NUDT15 and TPMT genes. Values are number of subjects (percentage) unless specified. Age means the age at the start of 6-MP maintenance therapy. ALL: Acute Lymphoblastic Leukemia, 6-MP: 6-Mercaptopurine, WT: Wild Type 
Table 2. Inter-ethnic variability of thiopurine toxicity-associated pharmacogenetic variants.

\begin{tabular}{|c|c|c|c|c|c|}
\hline & $\begin{array}{l}\text { East Asian } \\
(\mathrm{N}=504)\end{array}$ & $\begin{array}{l}\text { South Asian } \\
(\mathrm{N}=489)\end{array}$ & $\begin{array}{l}\text { European } \\
(\mathrm{N}=503)\end{array}$ & $\begin{array}{l}\text { American } \\
(\mathrm{N}=347)\end{array}$ & $\begin{array}{l}\text { African } \\
(\mathrm{N}=661)\end{array}$ \\
\hline \multicolumn{6}{|l|}{ NUDT15 } \\
\hline NM & $390(77.4 \%)$ & $421(86.1 \%)$ & $498(99.0 \%)$ & $312(89.9 \%)$ & $658(99.5 \%)$ \\
\hline $\mathrm{IM}$ & $80(\mathbf{1 5 . 9} \%)$ & $62(\mathbf{1 2 . 7} \%)$ & $2(0.4 \%)$ & $27(7.8 \%)$ & $1(\mathbf{0 . 2} \%)$ \\
\hline PM & $8(1.6 \%)$ & $3(0.6 \%)$ & & $2(0.6 \%)$ & \\
\hline Indeterminate & $26(5.2 \%)$ & $3(0.6 \%)$ & $3(0.6 \%)$ & $6(1.7 \%)$ & $2(0.3 \%)$ \\
\hline \multicolumn{6}{|l|}{ TPMT } \\
\hline NM & $481(95.4 \%)$ & $472(96.5 \%)$ & $463(92.0 \%)$ & $301(86.7 \%)$ & $520(78.7 \%)$ \\
\hline $\mathrm{IM}$ & $22(4.4 \%)$ & $17(3.5 \%)$ & $35(7.0 \%)$ & $40(\mathbf{1 1 . 5} \%)$ & $77(\mathbf{1 1 . 6} \%)$ \\
\hline PM & & & & $2(0.6 \%)$ & $6(0.9 \%)$ \\
\hline Indeterminate & $1(0.2 \%)$ & & $5(1.0 \%)$ & $4(1.2 \%)$ & $58(8.8 \%)$ \\
\hline \multicolumn{6}{|l|}{ IL6, CRIMI } \\
\hline Both WT & $269(53.4 \%)$ & $440(90.0 \%)$ & $478(95.0 \%)$ & $281(81.0 \%)$ & $658(99.5 \%)$ \\
\hline CRIM1 rs3821169 heterozygote only & $177(35.1 \%)$ & $46(9.4 \%)$ & $9(1.8 \%)$ & $13(3.7 \%)$ & $1(0.2 \%)$ \\
\hline IL6 rs13306435 heterozygote only & $14(\mathbf{2 . 8 \%})$ & $3(\mathbf{0 . 6 \%})$ & $15(\mathbf{3 . 0 \%})$ & $48(\mathbf{1 3 . 8 \%})$ & $2(0.3 \%)$ \\
\hline CRIM1 rs3821169 homozygote only & $33(6.5 \%)$ & 0 & 0 & 0 & 0 \\
\hline $\begin{array}{l}\text { IL6 rs } 13306435 \text { heterozygote and CRIMI } \\
\text { rs3821169 hetero- or homozygote }\end{array}$ & $10(\mathbf{2 . 0} \%)$ & 0 & 0 & $4(1.2 \%)$ & 0 \\
\hline $\begin{array}{l}\text { IL6 rs } 13306435 \text { homozygote and CRIMI } \\
\text { rs3821169 heterozygote }\end{array}$ & $1(\mathbf{0 . 2} \%)$ & 0 & $1(0.2 \%)$ & $1(\mathbf{0 . 2} \%)$ & 0 \\
\hline
\end{tabular}


Whole genome sequences of multiple ethnic groups were obtained from the 1000 Genomes Project (N=2504). Haplotypes and diplotypes were determined by the CPIC allele-definition tables and molecular phenotypes by the CPIC diplotype-phenotype matching tables. NM: Normal Metabolizer, IM: Intermediate Metabolizer, PM: Poor Metabolizer. 
Table 3. Contingency Tables for predicting thiopurine intolerance (DIP $<25 \%$ ) of two-, three-, and four-gene models in pediatric ALL patients $(N=320)$.

(a)

\begin{tabular}{lccc}
\hline \multirow{2}{*}{ STAR $^{\text {NUDT15, TPMT }}$} & \multicolumn{2}{l}{ DIP (\%) } & \\
\cline { 2 - 4 } & $\leq 25$ & $>25$ & Total \\
\hline PM+IM & 23 & 57 & 80 \\
NM & 21 & 219 & 240 \\
\hline Total & 44 & 276 & 320 \\
\hline
\end{tabular}

(b)

\begin{tabular}{lccc}
\hline \multirow{2}{*}{ GVB $^{\text {NUDT15, TPMT }}$} & \multicolumn{2}{l}{ DIP $(\%)$} & Total \\
\cline { 2 - 3 } & $\leq 25$ & $>25$ & \\
\hline$\leq 0.3$ & 23 & 53 & 76 \\
$>0.3$ & 21 & 223 & 244 \\
\hline Total & 44 & 276 & 320 \\
\hline
\end{tabular}

(c)

\begin{tabular}{llll}
\hline \multirow{2}{*}{ GVB $^{\text {NUDT15, TPMT, IL6 }}$} & DIP (\%) & Total \\
\cline { 2 - 3 }$\leq 0.3$ & $\leq 25>25$ & \\
\hline$>0.3$ & 23 & 51 & 74 \\
\hline Total & 21 & 225 & 246 \\
\hline
\end{tabular}

(d)

\begin{tabular}{llll}
\hline GVB $^{\text {NUDT15, TPMT, IL6, }}$\begin{tabular}{ll} 
DIP (\%) \\
\cline { 2 - 3 }
\end{tabular} & \multicolumn{2}{l}{ DIM } & Total \\
\hline$\leq 0.3$ & 28 & 60 & 88 \\
$>0.3$ & 16 & $\mathbf{2 1 6}$ & 232 \\
\hline Total & 44 & 276 & 320 \\
\hline
\end{tabular}

(e)

\begin{tabular}{|c|c|c|c|}
\hline \multirow{2}{*}{$\begin{array}{c}\text { GVBNUDT15, TPMT, } \\
\text { CRIM1^(r13306435, rs3821169*) }^{*}\end{array}$} & \multicolumn{2}{|c|}{ DIP (\%) } & \multirow{2}{*}{ Total } \\
\hline & $\leq 25$ & $>25$ & \\
\hline$\leq 0.3$ & 31 & 64 & 95 \\
\hline$>0.3$ & 13 & 212 & 225 \\
\hline Total & 44 & 276 & 320 \\
\hline
\end{tabular}

(f)

\begin{tabular}{|c|c|c|c|}
\hline \multirow{2}{*}{$\begin{array}{l}\underset{\text { GVB }}{\text { NUDT15, TPMT, IL6, }} \\
\text { CRIM1^(rs13306435, rs3821169*) }^{*} \text { (r) }\end{array}$} & \multicolumn{2}{|c|}{ DIP (\%) } & \multirow{2}{*}{-Total } \\
\hline & $\leq 25$ & $>25$ & \\
\hline$\leq 0.3$ & 31 & 63 & 94 \\
\hline$>0.3$ & 13 & 213 & 226 \\
\hline Total & 44 & 276 & 320 \\
\hline
\end{tabular}

(g)

\section{Prediction Models}

(a) STAR NUDT15, TPMT

(b) GVB NUDT15, TPMT

(c) GVB NUDT15, TPMT, IL6

(d) GVB NUDT15, TPMT, CRIM1*

(e) GVB NUDT15, TPMT, CRIM1^(r13306435, rs3821169*)

(f) GVB ${ }^{\text {NUDT15, TPMT, IL6, CRIM1^(rs13306435, rs3821169*) }}$

\begin{tabular}{ccccccccc}
$\begin{array}{c}\text { Sensitivity Specificity } \\
(\%)\end{array}$ & $\begin{array}{c}\text { PPV } \\
(\%)\end{array}$ & $\begin{array}{c}\text { NPV } \\
(\%)\end{array}$ & OR & $\begin{array}{c}\text { Relative } \\
\text { Risk }\end{array}$ & PAF & NNT & NNG \\
\hline 52.27 & 79.35 & 28.75 & 91.25 & 4.21 & 3.286 & 0.364 & 5.000 & 20.000 \\
52.27 & 80.80 & 30.26 & 91.39 & 4.61 & 3.516 & 0.374 & 4.618 & 19.442 \\
52.27 & $\mathbf{8 1 . 5 2}$ & 31.08 & 91.46 & 4.83 & 3.641 & 0.379 & 4.436 & 19.181 \\
64.64 & 78.26 & 31.82 & 93.10 & 6.30 & 4.614 & 0.498 & 4.013 & 14.591 \\
70.46 & 76.81 & 32.63 & 94.22 & 7.90 & 5.648 & 0.580 & 3.724 & 12.544 \\
$\mathbf{7 0 . 4 6}$ & 77.17 & $\mathbf{3 2 . 9 8}$ & $\mathbf{9 4 . 2 5}$ & $\mathbf{8 . 0 6}$ & $\mathbf{5 . 7 3 3}$ & $\mathbf{0 . 5 8 2}$ & $\mathbf{3 . 6 7 3}$ & $\mathbf{1 2 . 5 0 3}$ \\
\hline
\end{tabular}


DIP (\%): the last-cycle 6-MP Dose Intensity Percentage, PAF: Population Attributable Fraction, NNT: Number Needed to Treat, NNG: Number Needed to Genotype, M: Poor Metabolizer, IM: Intermediate Metabolizer, STAR ${ }^{\text {NUDT15, TPMT: }}$ classical star $\left(^{*}\right)$ allele-based haplotyping of NUDT15

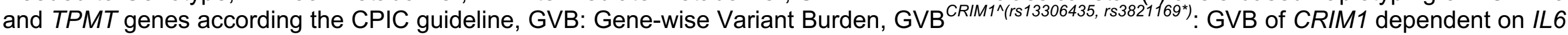
rs13306435 or CRIM1 rs3821169 homozygote. GVB cutoff value of 0.3 was selected as maximized Youden's index. 
Supplementary Table S1. Candidate variants among 115 ALL patients of all wild types for NUDT15, TPMT, IL6 and CRIM1.

\begin{tabular}{llcccccccc}
\hline Variant rsID & Gene & $\begin{array}{c}\text { Carrier } \\
(\%)\end{array}$ & $\begin{array}{c}\text { Hetero/ } \\
\text { Homozygote }\end{array}$ & $\begin{array}{c}\text { Carrier DIP } \\
(\text { mean } \pm \text { SD })\end{array}$ & $\begin{array}{c}\text { Non-carrier DIP } \\
\text { (mean } \pm \text { SD })\end{array}$ & SIFT & CADD & ExAC $^{*}$ & $P^{*}$ \\
\hline rs191083003 & FSIP2 & $2.6 \%$ & $3 / 0$ & $26.4 \pm 20.3$ & $72.5 \pm 28.9$ & 0.01 & 26.7 & 0.003 & 0.0260 \\
rs12587478 & KLHL33 & $5.2 \%$ & $5 / 1$ & $44.9 \pm 22.4$ & $72.8 \pm 29.3$ & 0 & 25.0 & 0.040 & 0.0136 \\
rs200982819 & SLC15A3 & $6.1 \%$ & $6 / 1$ & $50.6 \pm 21.1$ & $72.7 \pm 29.6$ & 0 & 29.7 & 0.028 & 0.0164 \\
rs67877771 & IQCG & $32.3 \%$ & $35 / 2$ & $61.9 \pm 25.4$ & $75.8 \pm 30.5$ & 0.04 & 26.2 & 0.215 & 0.0059 \\
rs61758536 & SPAG8 & $13.9 \%$ & $16 / 0$ & $60.5 \pm 22.5$ & $73.1 \pm 30.3$ & 0 & 26.0 & 0.052 & 0.0297 \\
rs34337292 & OR9Q2 & $26.1 \%$ & $29 / 1$ & $63.1 \pm 24.8$ & $74.2 \pm 30.7$ & 0 & 25.9 & 0.068 & 0.0263 \\
\hline
\end{tabular}

* $p$-value by one-sided T-test, DIP: Dose Intensity Percentage 